\title{
Quality of Work Life among Women Employees Working in RMG Sector of Bangladesh
}

\author{
Tanjela Hossain $^{1^{*}}$, Hasan Shirazi ${ }^{2}$
}

${ }^{1}$ Senior Lecturer in HRM, Department of Business Administration, Central Women's University, Dhaka, BANGLADESH

${ }^{2}$ Associate Professor and Chairperson, Department of Business Administration, Central Women's University,

Dhaka, BANGLADESH

*Corresponding Contact:

Email: tanjela.hossain@gmail.com

DOI: https://doi.org/10.18034/gdeb.v7i1.106

\begin{abstract}
"Quality of work life" has become the buzzword for the contemporary organization. Employees are more concern about their work environment ever, which is one of the most important factors to determine the quality of work life (QWL). It refers to the favorableness or unpleasantness of a job environment for people. The increased complexity of today's work environment poses several challenges, especially for women employees who are working in different garment factories. It is now the high time for the Ready-made Garment (RMG) sector to be aware of improving the QWL. Our study focused on the factors influencing the quality of work life of women employees, their level of job satisfaction. We have tried to assess the QWL of women employees working in selected garment factories which are located in Gazipur district. We have collected data through a semi-structured questionnaire from a sample of 500 women employees. The findings of the study project various indications about concerned issues where the organization can concentrate to bring about better QWL life so that they get more satisfied women workforce. For statistical analysis mean, percentage, hypothesis testing, ranking order method and weighted average method were calculated. The ultimate findings of the study reveal that there is a significant relationship between work experience and participation in decision making for women employees. The survey study also shows that authority's willingness is also an influential parameter to improve the QWL. Another interesting finding of our survey focuses that women employees have been given the least priority to salary as a measure to enhance QWL.
\end{abstract}

Key Words: Quality of work life (QWL), Job satisfaction, Work environment, Work flexibility \& Performance, RMG

\section{INTRODUCTION}

Human resource is essential to the success of today's organization. In the present context, organizations need to be more concerned about the work environment so that they are well equipped to develop their workforce and enjoy the productivity of the committed workforce. Therefore, organizations need to develop a strategy to improve the employees 
"Quality of Work Life" (QWL) to satisfy both the organizational objectives and employee needs. There is no generally accepted definition of this term-Quality of Work Life (QWL). It refers to the favorableness or unpleasantness of a job environment for people. Good quality of work life not only attracts new talent but also helps to retain the existing talent. Quality of work life involves job security, good working conditions, adequate and fair compensation and equal employment opportunity altogether. QWL aims to meet the twin goals of the enhanced effectiveness of the organization and improved quality of life at the workplace for employees that means to create a Win-Win situation for both sides. But today's employees would not believe in such values of work. Employees work for a salary and continue to work if the conditions of work are encouraging and pleasant, and terms of employment are favorable to the individual, the endure with the organization otherwise look for better opportunities. Women are considered as the major working group in the textile and garment industries of the country. These industries are more labor-intensive and require the finest output at the end. QWL consists of opportunities for active involvement in group working arrangements or problem solving that are of mutual benefit to employees or employers, based on labor-management cooperation.

Good Quality of work-life is necessary for an organization to attract and to retain skilled and talented employees. To survive in the competitive market because of liberalization, privatization, and globalization and to minimize the turnover rate of employees the QWL initiatives are very important. QWL involves a wide variety of components that are influenced by the performance of employees. The Bangladesh Ready-Made Garment industry has grown over the space of a few short decades to become the second largest in the world. The RMG sector has become a key driver of Bangladesh's economy and the nation's development. Women are considered as the major working group the textile and Garment Industries of the country.

\section{REVIEW OF LITERATURE}

\section{Meaning of Quality of Work-Life}

QWL is described as the favorable working environment that supports and promotes satisfaction by providing employees with rewards, job security, career growth opportunities, etc. Hackman (1980) identified that the work environment that can fulfill employees' personal needs is considered to provide a positive interaction effect, which leads to an excellent QWL. Cunningham and Eberle (1990) emphasized the personal needs that is satisfied when rewards from the organization, such as compensation, promotion, recognition, and development meet their expectations. Chan and Einstein (1990) explained QWL as a reflection of concern for employees' experience at work, their relationship with other people, their work setting and their effectiveness on the job. It is a complex, multidimensional, generic concept (Hsu \& Kernohan, 2006). Most literature on the QWL originates from the discipline of Industrial Labor Relationships (Hsu \& Kernohan, 2006). QWL has been defined by researchers in different ways, which has brought about certain counterparts such as work quality, function of job content, employee's well-being, the quality of the relationship between employees, working environment, and the balance between job demands and decision autonomy or the balance between control need and control capacity (Korunka, Hoonakker, \& Carayon, 2008) QWL is thus recognized as a multi-dimensional construct and the categorization is neither universal or eternal. Different researchers have come up with different categories and factors to define and measure the quality of life. Walton (1980) divided QWL main components into four categories such as 
work meaningfulness, work social and organizational equilibrium, work challenge and richness. Klatt, Murdick, and Schuster (1985) have identified eleven dimensions of QWL in the year. They are pay, occupational stress, organizational health programs, alternative work schedule, participate management and control of work, recognition, superiorsubordinate relations, grievance procedure, adequacy of resources, seniority and merit in promotion and development and employment on a permanent basis.

Quality of work life refers to the relationship between employees and their total working environment. It considers people as an asset to the organization rather than cost. This approach believes that people can perform to their best if they are given enough autonomy in managing their work and make a decision. And, so the quality of work life is viewed as an alternative to the control approach to managing people. Warret al. (1979) defined the quality of working life as indicative of a variety of apparently relevant factors, including work involvement, intrinsic job motivation, the higher order need strength, perceived intrinsic job characteristics, job satisfaction, life satisfaction, happiness, and self-rated anxiety. Zare, Hamid, Haghgooyan, Zolfa and Asl, Zahra Karimi (2012) undertook a study on quality of work life to identify its dimensions Library method was used to gather information on theoretical basics, literature and to identify aspects and scales. Field study method was used to gather information through questionnaires distributed among 30 experts. The data so collected was analyzed using Analytical Hierarchy Process (AHP); it is found that QWL can be explained by four factors as given under.

- Work-life balance - Fair working hours, Work-life atmosphere, Opportunity for doing religious ceremonies, Ergonomics, No physical and mental damages, Distance between workplace and home

- Social factors - The importance of work in the society, social integration in an organization, Social networks in work, respecting employees, Self-esteem feeling in the organization, Good colleagues

- $\quad$ Economic factors - Salary, Health service, Insurance, Retirement, Job security

- Job content - Team working, independence, meaningful work, rich and challenging work, ownership feeling in work, the need for creativity in work, growth opportunity.

\section{Dimensions in QWL}

When it comes to categorization, the following classifications can be found - (i) the mental and objective aspects of work life (Casio, 1998), (ii) lower- and higher order needs (Sirgy et al., 2001) and (iii) job characteristics, and supervisory, structural and social characteristics (Winter et al., 2000). The factors that were stated by different researchers are grouped and stated in Table -. The key concepts captured and discussed in the existing literature include job security, better reward systems, higher pay, the opportunity for growth, and participative groups, among others (Havlovic, 1991; Straw and Heckscher, 1984; Scobel, 1975).

Table 1: Dimension and factors of quality of life

\begin{tabular}{|l|l|}
\hline \multicolumn{1}{|c|}{ Dimension } & \multicolumn{1}{|c|}{ Factors } \\
\hline Job design & $\begin{array}{l}\text { Job content, work meaningfulness, work challenges, work richness, } \\
\text { meaningful job and autonomy in the job, work restructuring, and } \\
\text { job/role clarity. }\end{array}$ \\
\hline $\begin{array}{l}\text { Work environment } \\
\text { and facilities }\end{array}$ & Improving the work environment, social and welfare facilities, etc. \\
\hline
\end{tabular}




\begin{tabular}{|c|c|}
\hline Dimension & Factors \\
\hline Job security & Employment on the permanent basis. \\
\hline $\begin{array}{l}\text { Health, stress, } \\
\text { and safety }\end{array}$ & $\begin{array}{l}\text { Health and safety of working conditions, protection against disease } \\
\text { and injury within and outside the workplace; occupational stress, } \\
\text { organizational health programs, job stress, and lack of job burnout. }\end{array}$ \\
\hline $\begin{array}{l}\text { Wages and } \\
\text { rewards }\end{array}$ & $\begin{array}{l}\text { Fair and adequate pay, fair and proper payment for good } \\
\text { performance, Innovative rewards systems, the circumstances and } \\
\text { procedures relating to promotion policies, seniority and merit in } \\
\text { promotion and development. }\end{array}$ \\
\hline Work-life balance & Working hours and alternative work schedule. \\
\hline $\begin{array}{l}\text { Aesthetics and } \\
\text { creativity }\end{array}$ & $\begin{array}{l}\text { sthetics, free time in the workplaces, creativity workplace } \\
\text { al creativity. }\end{array}$ \\
\hline Conflict & $\begin{array}{l}\text { Cooperative work between colleagues, adequacy of resources, work, } \\
\text { and organizational equilibrium, and grievance procedure. }\end{array}$ \\
\hline $\begin{array}{l}\text { Learnir } \\
\text { develor }\end{array}$ & $\begin{array}{l}\text { Increased emphasis on employee skill development, possibility of } \\
\text { learning and using new skills, training to improve job skills, creating } \\
\text { opportunities to learn, growth in the professionalism path, job } \\
\text { growth and career progress }\end{array}$ \\
\hline $\begin{array}{l}\text { Leadership and } \\
\text { employee } \\
\text { empowerment }\end{array}$ & $\begin{array}{l}\text { Superior-subordinate relations, Participatory supervision, } \\
\text { Communication, desire and motivation to work, creating work and } \\
\text { organizational commitment, employee involvement, participation, } \\
\text { and power, Increased autonomy for action and decision making at the } \\
\text { worker level, access to relevant information and participative problem } \\
\text { solving, }\end{array}$ \\
\hline Job satisfaction & $\begin{array}{l}\text { Recognition and appreciation of the work inside and outside the } \\
\text { organization, membership in successful teams, proud of the job, and } \\
\text { lack of turnover intentions. }\end{array}$ \\
\hline
\end{tabular}

\section{Statement of the Problem}

Low Quality of work-life conflict hampers the happiness of female employees in the workplace that leads to lower productivity, absenteeism, high turnover rate, etc to the organization. While many studies find deleterious effects of low quality of work-life on growth, human development, some papers remain ambiguous.

Bangladesh is an interesting case to study the level of Quality of work-life and its effects especially in the field of RMG where maximum employees are female. This raises several questions:

- Whether Female Employees of RMG sector are happy with their work environment or not?

- Are Women Employees satisfied regarding various measures taken by the organization for improving Quality of Work life?

- Do they have any persistent problems that they don't seem to be able to solve?

- What kinds of solutions do Female Employees of RMG sector can come up with for the problems that they have identified?

The paper intends to answer these questions. 


\section{OBJectives OF THE Study}

General Objective: The main objective of this paper is to investigate the level of Quality of Work-life for Female Employees of RMG sector in Bangladesh

Specific Objectives: The specific objectives are:

- To assess the quality of work life for women employees in RMG Sector.

- To analyze the association among different issues related to Quality of Work Life.

- To assess Women Employee's level of satisfaction regarding various measures to be taken by the organization for improving Quality of Work life

- To get reflection about women employee's expectations regarding different issues to improve their QWL

\section{Methodology OF THE Study}

Research design: The research is descriptive analytical and empirical.

Study Place: Gazipur, Dhaka, Bangladesh

Study Period: February 2017 - November 2017

Study Target Population: Garment factories located in Dhaka and near Dhaka City were selected purposively as the target population of the study. It is to be noted that about 500 female employees of different garment factories who are in operation in Dhaka and near Dhaka city are targeted for the study. The universe of the study comprises of Women employees working in Garment factories in Dhaka.

Sampling Technique: The sample was chosen using the snowball method (Singeton and Straits, 1999), source: Singleton, R. A. \& Straits, B. C. (1999). Approach as to Social Research, Oxford: Oxford University Press, whereby each respondent was asked to introduce two colleagues or friends.

Sample \& Sample Size: Total samples of 500 female employees of different garment factories. First, we selected 75 Female employees who are working at the different position in different garment factories randomly and then each of 75 female employees was requested to introduce two colleagues or friends and so on. The sample was restricted to mainly female workers. From the survey response, a total of 500 fully completed questionnaire were considered for analysis.

\section{Data Collection Technique and List of variables for preparing a Questionnaire}

Data were obtained by using a day long, face-to-face or telephone interviews with 75 female employees of 3 different garment factories.

They were asked to give opinions on the five-point scale extending from strongly significant to not at all significant, strongly satisfied to strongly dissatisfied, strongly agree to strongly disagree. They are interviewed by using a semi-structured questionnaire. After that, we give our questionnaire to other female workers. Though some findings are extracted from our observations.

\section{List of Key Variables for preparing a Questionnaire}

To understand Quality of work life and level of satisfaction of female employees a questionnaire has been prepared based on the following items:

- Perceptions of respondents toward various factors influencing Quality of work life 
- Various parameters regarding Quality of work life

- Women Employee's level of satisfaction regarding various measures to be taken by organization for improving Quality of Work life

- Women employee's level of satisfaction with work-life interactions.

- Women employee's level of satisfaction with work flexibility, autonomy, etc

Analytical tools used

By analyzing the level of Quality of work life and level of satisfaction of the surveyed organizations, we tried to conclude by using our own analytical and cognitive abilities. Microsoft Excel and IBM SPSS version 22 software have been used to process survey data. Hypothesis testing through Chi-square test, Simple average method or percentage method has been used to calculate quantitative data converted from qualitative data collected through semi-structured questionnaire.

\section{DATA ANALYSIS AND INTERPRETATION}

Respondents were asked a series of open questions, semi-open questions, multiple choice questions, dichotomous questions. Findings and Analysis are presented below based on the questions of the questionnaire used in this study:

\section{The demographic profile of the respondents}

At the very beginning of our data collection, we classify the respondents based on their age, monthly family income, qualification, experience, and marital status for their responses regarding the quality of work life.

Table 2: Demographic factors of the respondents

\begin{tabular}{|c|c|c|}
\hline Demographic factors & No. of Respondents & Percentage (\%) \\
\hline \multicolumn{3}{|l|}{ Age: } \\
\hline a) Below 20 years & 112 & $22.4 \%$ \\
\hline b) 20-30 years & 183 & $36.6 \%$ \\
\hline c) $30-40$ years & 96 & $19.2 \%$ \\
\hline d) 40-50 years & 78 & $15.6 \%$ \\
\hline e) 50 and above & 31 & $6.2 \%$ \\
\hline \multicolumn{3}{|c|}{ Educational Qualification: } \\
\hline No Formal Education & 86 & $17.2 \%$ \\
\hline School Level & 189 & $37.8 \%$ \\
\hline Diploma or Equivalent & 84 & $16.8 \%$ \\
\hline Graduation & 59 & $11.8 \%$ \\
\hline Post-Graduation & 82 & $16.4 \%$ \\
\hline \multicolumn{3}{|l|}{ Experience: } \\
\hline Less than a year & 124 & $24.8 \%$ \\
\hline 1 year -3 years & 196 & $39.2 \%$ \\
\hline 3 years -5 Years & 83 & $16.6 \%$ \\
\hline 5 years -7 Years & 64 & $12.8 \%$ \\
\hline More than 7 years & 33 & $6.6 \%$ \\
\hline \multicolumn{3}{|l|}{ Marital Status: } \\
\hline a) Unmarried & 128 & $25.6 \%$ \\
\hline b) Married & 187 & $37.4 \%$ \\
\hline c) Divorced & 98 & $19.6 \%$ \\
\hline
\end{tabular}




\begin{tabular}{|l|c|c|}
\hline d) Single Parent & 87 & $17.4 \%$ \\
\hline Income in Tk. (per month): & 153 & $30.6 \%$ \\
\hline a) Less than 10000 & 146 & $29.2 \%$ \\
\hline b) $10000-20000$ & 112 & $22.4 \%$ \\
\hline c) $20000-30000$ & 49 & $9.8 \%$ \\
\hline d) $30000-40000$ & 40 & $8 \%$ \\
\hline e) $40000+$ &
\end{tabular}

Table 2 highlights that the age range of majority (36.6\%) of female employees is between 20 to 30 years, $22.4 \%$ were in below 20 years age group, $19.2 \%$ is between 30 to 40 years age group. $15.6 \%$, and $6.2 \%$ respondents were in age group of between 40 to 50 years and above 50 years respectively. The table also indicates that most female employees $(37.8 \%)$ have only school level educations, $17.2 \%$ are uneducated, $16.8 \%$ have Diploma. Only $11.8 \%$ are graduates and $16.4 \%$ are postgraduates. It is also clear from the table that $24.8 \%$ of the respondents had experienced less than one year, $39.2 \%$ had experience between $1-3$ years, $16.6 \%$ of the respondents had $3-5$ years of experience, $12.8 \%$ of the respondents had 5-7 years of experiences and only $6.6 \%$ hold more than 7 years of experience. In this study, most of the female employees (37.4\%) are married, $25.6 \%$ are unmarried, $19.6 \%$ are divorced and $17.4 \%$ are single parents.

Only $8 \%$ of the respondents have a monthly income of above Tk.40,000, $9.8 \%$ are in the income category of Tk.30,000-40,000, 22.4\% are in the income category of Tk.20,000-30,000, $29.2 \%$ are in the income category of Tk.10,000-20,000 and $30.6 \%$ are in the income category of below Tk.10,000.

\section{Perceptions of respondents toward various factors influencing Quality of work life}

Influencing Factors in Quality of Work Life: RMG sector is highly Labor-intensive sector that is why we must measure the women employee's perception of their working environment first. What women employees are expecting from the workplace and which factors are most influential \& important to them were identified in the following table. There are many factors regarding the quality of work life. The respondents were asked to rate nine influential factors on five-point Likert-scales.

Table 3: Perception of respondents towards various Factors regarding QWL

\begin{tabular}{|c|l|c|c|c|}
\hline $\begin{array}{c}\text { Sl. } \\
\text { No. }\end{array}$ & $\begin{array}{l}\text { Various Parameters regarding Quality of work } \\
\text { life ("Highly Satisfied to Highly Dissatisfied") }\end{array}$ & $\begin{array}{c}\text { Mean } \\
\text { Score }\end{array}$ & Variance & $\begin{array}{c}\text { Standard } \\
\text { Deviation }\end{array}$ \\
\hline $\mathbf{1 .}$ & Health and safety measures & 3.568 & 1.272 & 1.128 \\
\hline $\mathbf{2 .}$ & Opinion about working hours & 2.948 & 2.037 & 1.427 \\
\hline 3. & Opinion about workload & 2.756 & 2.261 & 1.504 \\
\hline $\mathbf{4 .}$ & Opinion about Respect at workplace & 3.436 & 1.585 & 1.259 \\
\hline $\mathbf{5 .}$ & Relationship with co-worker & 3.828 & 1.445 & 1.202 \\
\hline $\mathbf{6 .}$ & $\begin{array}{l}\text { Training programs are given by the } \\
\text { organization }\end{array}$ & 3.124 & 1.776 & 1.333 \\
\hline 7. & Grievance handling procedure & 3.108 & 1.471 & 1.213 \\
\hline $\mathbf{8 .}$ & $\begin{array}{l}\text { Satisfaction about feedback given on Job } \\
\text { Performance }\end{array}$ & 2.46 & 1.6 & 1.265 \\
\hline
\end{tabular}

Table 3 shows the responses towards Influential Parameters regarding the quality of work life. The mean scores infer (as the scale is taken from highly satisfied $=5$ to highly dissatisfied=1) that the women employees of Garments are highly satisfied with the working relationship with their co-workers (3.828) and Health \& safety measures taken by 
authority (3.568). It also infers that women workers are highly dissatisfied with the given feedback on their job performance (2.46).

Perception of women employees about the organizational requirement to take part in the decision-making process: Here we tried to find out the perception of women employees about the organizational requirement to participate in decision-making process. A simple percentage analysis was administered in the following table 4 (a).

Table 4(a): Perception of women employees

\begin{tabular}{|l|c|c|}
\hline Factors & No. of Respondents & Percentage (\%) \\
\hline Job Experiences & 52 & 10.4 \\
\hline Outstanding Performance & 94 & 18.8 \\
\hline The Willingness of Management & 354 & 70.8 \\
\hline Total & $\mathbf{5 0 0}$ & $\mathbf{1 0 0}$ \\
\hline
\end{tabular}

From table 4 (a) depicts that $70.8 \%$ of 500 women employees believe that participation in decision making depends on the willingness of management. So, it can easily be said that women employee's participation in decision making does not depend on job performance or job experiences rather on the willingness of authority.

\section{Analysis of Relationship between work experience and participation in decision making}

Here we try to find out the relationship between total work experience of the women workers and their participation in decision making by using Chi-Square analysis.

Null Hypothesis: There is no significant relationship between the total work experience of the women employees and their participation in decision making.

Alternate Hypothesis: There is a significant relationship between the total work experience of the women employees and their participation in decision making.

Table 4(b): Scenario between the total work experience of the women employees and their participation in decision making

\begin{tabular}{|c|c|c|c|}
\hline \multirow{2}{*}{ Total Work Experience } & \multicolumn{3}{|c|}{ No. of Respondents } \\
\hline & yes & No & Total \\
\hline Less than a year & 1 & 123 & 124 \\
\hline 1 year -3 years & 19 & 177 & 196 \\
\hline 3 years -5 years & 10 & 73 & 83 \\
\hline 5 years -7 years & 13 & 51 & 64 \\
\hline 7 years and above & 9 & 24 & 33 \\
\hline TOTAL & 52 & 448 & 500 \\
\hline
\end{tabular}

Table 4(c): Calculated Chi-Square value and Table Value

\begin{tabular}{|c|c|c|c|c|c|}
\hline $\begin{array}{c}\text { S1. } \\
\text { No }\end{array}$ & \multicolumn{1}{|c|}{ Factor } & $\begin{array}{c}\text { Calculated } \chi^{2} \\
\text { Value }\end{array}$ & $\begin{array}{c}\text { Degrees of } \\
\text { Freedom }\end{array}$ & $\begin{array}{l}\text { Table } \\
\text { Value }\end{array}$ & \multicolumn{1}{|c|}{ Remarks } \\
\hline 1. & $\begin{array}{l}\text { Work Experience \& } \\
\text { Employee's } \\
\text { participation in } \\
\text { Decision Making }\end{array}$ & $\mathbf{2 9 . 4 2 4 5}$ & $\mathbf{4}$ & $\mathbf{9 . 4 8 8}$ & $\begin{array}{l}\text { Calculated } \chi^{2} \text { value is } \\
\text { more than the Table value } \\
\text { and the null hypothesis is } \\
\text { rejected }\end{array}$ \\
\hline
\end{tabular}

Table 4(b) and Table 4(c) shows the calculated value 29.4245 is more than the table value at $5 \%$ level of significance. So, the null hypothesis is rejected. Hence there is a relationship between the total work experience of the women employees and their participation in decision making. 


\section{Women Employee's level of Priority regarding various measures to be taken by the} organization for improving Quality of Work life

Here we tried to rank the Priority of women employees regarding different measures to be taken by garment factories through weighted average method.

Table 5: Priority ranks given by the women employees regarding the QWL factors of the garment factories

\begin{tabular}{|l|l|c|c|c|c|c|c|c|c|}
\hline No & \multicolumn{1}{|c|}{ Factors } & $\begin{array}{c}\text { SDA } \\
\mathbf{( 1 )}\end{array}$ & $\begin{array}{c}\text { DA } \\
\mathbf{( 2 )}\end{array}$ & $\begin{array}{c}\text { N } \\
\mathbf{( 3 )}\end{array}$ & $\begin{array}{c}\text { A } \\
\mathbf{( 4 )}\end{array}$ & $\begin{array}{c}\text { SA } \\
\mathbf{( 5 )}\end{array}$ & $\begin{array}{c}\text { Weighted } \\
\text { Average }\end{array}$ & $\begin{array}{c}\text { Weighted } \\
\text { Score }\end{array}$ & Rank \\
\hline 1. & Salary & 52 & 191 & 81 & 102 & 74 & 1455 & 97 & 7 \\
\hline 2. & Empowerment & 75 & 84 & 97 & 131 & 113 & 1623 & 108.2 & 5 \\
\hline 3. & Health \& Safety & 75 & 122 & 63 & 147 & 93 & 1561 & 104.07 & 6 \\
\hline 4. & Job Security & 48 & 109 & 51 & 209 & 83 & 1670 & 111.33 & 4 \\
\hline 5. & Work environment & 12 & 45 & 63 & 186 & 194 & 2005 & 133.67 & 1 \\
\hline 6. & Leave \& holidays & 5 & 93 & 59 & 245 & 98 & 1838 & 122.53 & 2 \\
\hline 7. & Work time flexibility & 22 & 128 & 43 & 223 & 84 & 1719 & 114.6 & 3 \\
\hline
\end{tabular}

(SDA=Strongly Disagree, $D A=$ Disagree, $N=$ Neutral, $A=$ Agree, $S A=$ Strongly Agree)

Table 5 shows the priority given by the women employees to reflect their expectation from the organization for the improvement of the quality of life. The ranking shows that work environment has given the most priority to improve the quality of work life. Entitled Leave and holidays are also addressed as a priority. Interestingly table reveals the least priority to salary as a measure to improve the quality of work life.

\section{Work-life Interaction}

Work-life Interaction indicates the relationship between work of female employees and their responsibilities or activities outside of work with family or friends. Work-life Interaction also refers to the relationship between work or job of female employees and the ability to develop or maintain connections and friendships in their community.

Table 6: Interference between work responsibilities and activities outside of work

\begin{tabular}{|l|l|l|l|l|l|l|}
\hline Scale of Attitude & Almost always & Often & Sometimes & Rarely & Never & Total \\
\hline Frequency & 43 & 246 & 109 & 70 & 22 & 500 \\
\hline Percentage & $8.6 \%$ & $49.2 \%$ & $21.8 \%$ & $14 \%$ & $4.4 \%$ & $100 \%$ \\
\hline
\end{tabular}

The table 6 shows that interference between work responsibilities and activities outside of work is occurred more often $(49.2 \%)$. From the above table, it can easily be said that the interference between work responsibilities and activities outside of work is obvious, in fact almost indispensable as only $4.4 \%$ of 500 women employees addressed never.

Table 7: How often does your work interfere with your ability to develop connections in your community?

\begin{tabular}{|l|l|l|l|l|l|l|}
\hline Scale of Attitude & Almost always & Often & Sometimes & Rarely & Never & Total \\
\hline Frequency & 143 & 113 & 77 & 102 & 65 & 500 \\
\hline Percentage & $28.6 \%$ & $22.6 \%$ & $15.4 \%$ & $20.4 \%$ & $13 \%$ & $100 \%$ \\
\hline
\end{tabular}

The table 7 shows that $28.6 \%$ of 500 women respondents addressed that their work responsibility interferes almost always their ability to develop a connection with the community. Whereas $13 \%$ said that there is no interference between work and the ability to develop connections. 


\section{Job Autonomy and Job Security}

We know job security and autonomy is a vital measure to improve the quality of work life. So, it needs to be assessed the level of autonomy and security a woman employee enjoying from her job place. In our survey question about job autonomy and security were given too.

Table 8: Job Autonomy and Job Security

\begin{tabular}{|c|c|c|c|c|c|c|}
\hline Scale of Attitude & Strongly Agree & Agree & Neutral & Disagree & Strongly Disagree & Total \\
\hline Frequency & 31 & 94 & 115 & 87 & 173 & 500 \\
\hline Percentage & $6.2 \%$ & $18.8 \%$ & $23 \%$ & $17.4 \%$ & $34.6 \%$ & $100 \%$ \\
\hline
\end{tabular}

The table 8 shows $6.2 \%$ female professionals strongly feel positive that they have complete job autonomy and job security in their job place. Whereas $34.6 \%$ women strongly feel that they do not have any job autonomy and job security.

\section{Work Flexibility}

Work flexibility means easiness to change the decisions or to get customized benefits or services from the authority of the organization in respect of selecting the location of work, scheduling of duties and responsibilities, getting chance to maintain adequate work and personal and family life balance and having job security at the organization. Work flexibility gives an employee more comfort to work with. It is often said that the higher the flexibility in the workplace, the higher the job satisfaction and quality of performance.

Table 9: Level of flexibility having in selecting the location of work

\begin{tabular}{|c|c|c|c|c|c|c|}
\hline Scale of Attitude & Completely & Often & Sometimes & Rarely & None & Total \\
\hline Frequency & 9 & 23 & 43 & 249 & 176 & 500 \\
\hline Percentage & $1.8 \%$ & $4.6 \%$ & $8.6 \%$ & $49.8 \%$ & $35.2 \%$ & $100 \%$ \\
\hline
\end{tabular}

The table 9 presents $8.6 \%$ female employees are neutral in respect of flexibility in selecting the location of work. $1.8 \%$ female employees feel that they have complete flexibility in selecting the location of work. Interestingly $49.8 \%$ near to half of our total respondents said that authority is rarely flexible in selecting the location. Moreover, $35.2 \%$ addressed that there is no flexibility in selecting the location of work.

Table 10: Level of flexibility having in scheduling work

\begin{tabular}{|c|c|c|c|c|c|c|}
\hline Scale of Attitude & Completely & Often & Sometimes & Rarely & None & Total \\
\hline Frequency & 14 & 53 & 134 & 167 & 132 & 500 \\
\hline Percentage & $2.8 \%$ & $10.6 \%$ & $26.8 \%$ & $33.4 \%$ & $26.4 \%$ & $100 \%$ \\
\hline
\end{tabular}

Above table 11 quotes that most of the female employees i.e. $33.4 \%$ get rarely the flexibility to schedule their work. Least number of female employees i.e. $2.8 \%$ can enjoy the complete flexibility to schedule their work activities.

Table 11: Level of flexibility to maintain adequate work and personal and family life balance

\begin{tabular}{|c|c|c|c|c|c|c|}
\hline Scale of Attitude & Strongly Agree & Agree & Neutral & Disagree & Strongly Disagree & Total \\
\hline Frequency & 11 & 39 & 61 & 203 & 186 & 500 \\
\hline Percentage & $2.2 \%$ & $7.8 \%$ & $12.2 \%$ & $40.6 \%$ & $37.2 \%$ & $100 \%$ \\
\hline
\end{tabular}

Above table 11 marks that most of the female employees i.e. 40.6\% women get rarely the flexibility to maintain adequate work and personal and family life balance. Whereas only $2.2 \%$ working women strongly feel that they have sufficient level of flexibility to maintain work-life balance. 


\section{FINDINGS OF THE STUDY}

The findings are presented based on different tools of analysis such as Simple Percentage analysis, Chi-Square Analysis and Weighted average, and ranking order method. It is observed that the women employees of the garment factory are highly satisfied with the working relationship with their co-workers and Health \& safety measures taken by the authority. It is also revealed from the study that women workers are highly dissatisfied about the feedback is given on their job performance from their superior. There is a significant relationship between the total work experience of the women employees and their participation in decision making. That means the experience is a matter of taking critical decision-making situations. It is also identified that women employee's participation in decision making is not only depending on job performance or job experiences but also on the willingness of authority. Women have given work environment as the most priority to improve the quality of work life. Entitled Leave and holidays are also addressed as a priority for better quality of work life. Interestingly our study reveals the least priority to salary as a measure to improve the quality of women's working life.

\section{CONCLUSION AND ReCOMmEndations}

The garment industry has played a pioneering role in the development of industrial sector of Bangladesh. RMG sector is now one of the main export areas of the country where maximum employees are women. A good quality of work life not only attracts young and new talent but also retain the existing experienced talent. The study indicates that increase in quality of work life results in an increase in job performance \& job satisfaction. The study reveals that only an attractive salary can't be the measure to improve QWL. A good working environment, good relationship with co-workers, respect as an employee, on time fair job evaluation, sense of participation, sense of job security etc. can make a healthy work-life for women employees. However, Grievance handling procedures, work-time flexibility, adequate work break \& weekends, different training and career counseling programs can be made at a satisfactory level to ensure a healthy work life. Furthermore, the study recommends that the experienced and expert women employees could be can be given a sense of participation in critical decision-making situations.

\section{REFERENCES}

Casio, W.F, (1998), Managing human resources: productivity, quality of work life, profits, Irwin: McGraw-Hill, Boston, MA., 1998

Chan, C. H., \& Einstein, W. O. (1990). Quality of Work Life (QWL): What can unions do? SAM Advanced Management J., 55, 17-22.

Cunningham, J. B., \& Eberle, T. (1990). A guide to job enrichment and redesign. Personnel, 67(2), 56-61.

Elizur, D., \& Shye, S. Quality of work life and its relation to quality of life. Applied Psychology: An International Review, 39 (3), 1990, 275-291.

Hackman, J. R., \& Oldham, G. R. (1980). Work redesign, Redesigns. M.A: Addison- Wesley.

Havlovic, S.J. (1991). Quality of work life and human resource outcomes. Industrial Relations, 30(3), 469-479

Hsu, M. Y., \& Kernohan, G. Dimensions of hospital nurses' quality of working life. Journal of Advanced Nursing, 54, 2006, 120-131.

Kalra, S. K., \& Ghosh, S. Quality of work life: A study of associated factors. The Indian Journal of Social Work, 1984, 45-54. 
Klatt, Murdick, and Schuster (1985), Human Resource Management, Ohio, Charter E. Merrul Publishing Company, pp.585-592.

Korunka, C., Hoonakker, P., \& Carayon, P. Quality of working life and turnover intention in information technology work. Human Factors and Ergonomics in Manufacturing \& Service Industries, 18, 2008, 409-423.

Robbins, S.P. (1989), Organizational Behavior: Concepts, Controversies, and Applications, PrenticeHall, Englewood Cliffs, NJ. [3] Klatt, Murdick and Schuster (1985), Human Resource Management, Ohio, Charter E. Merrul Publishing Company, pp.585-592.

S. Subhashini and Dr. C.S. Ramani Gopal (2013), "Quality of work life among women worker in garment factories in Coimbatore District" Asia pacific journal of Research.

Scobel, D.N. Doing away with the factory blue, Harvard Business Review, 53, 1975. 132-42.

Sirgy, M. J., Efraty, D., Siegel, P., \& Lee, D. J. (2001). A new measure of quality of work life (QWL) based on need satisfaction and spillover theories. Social Indicators Research, 55, 241-302.

Staines, G.L. (1980). Spillover versus compensation: A review of the literature on the relationship between work and nonwork, Human Relations, 33:111-129.

Sue Campbell Clark. (2000). Work/family Border Theory: A new Theory of Work/family Balance. Human Relations, 5: 23-31.

Walton, R.E. Improving the QWL, Harvard Business Review, 19 (12), May-June 1980, 11-24.

Warr, P, Cook, J and Wall, T (1979) Scales for the measurement of some work attitudes and aspects of psychological well-being. Journal of Occupational Psychology. 52, 129-148.

Winter, R., Taylor, T., and Sarros, J., Trouble at Mill, "Quality of Academic work-life issues within a comprehensive Australian University", Studies in Higher Education, 25 (3), 2000, 279-294.

Zare, Hamid, Haghgooyan, Zolfa and Asl, Zahra Karimi. Determining and Prioritizing the Criteria and Scales of Quality of Work Life (QWF) by AHP Method, European Journal of Social Sciences, 27(3), 2012, 346-359. 


\section{APPENDIX}

\section{Survey Questionnaire on}

\section{Quality of Work Life among Women Employees Working in RMG Sector of Bangladesh}

Please put the tick mark into your choices and write your opinions where necessary

1. Personal Demographic Information:

\begin{tabular}{|l|lll|}
\hline Gender & Female \\
\hline Age & a) below 20 $\quad$ b) 20-30 $\quad$ c) 30-40 $\quad$ d) 40-50 e) 50 and above \\
\hline Education & $\begin{array}{l}\text { a) Not educated } \\
\text { Post-graduation }\end{array}$ \\
\hline Marital Status & a) Unmarried, b) Married, c) Divorced, d) Single Parent \\
\hline Job Experience & a) Less than 1-year, b) 1-4 years, c) 4-7 years, d) 7-10 years, e) 10years+ \\
\hline
\end{tabular}

\section{Household Demographic Information:}

Household Income (In BDT): a) Less than 10000, b) 10000-20000, c) 20000-30000, d) 30000-40000, e) $40000+$

3. Perceptions of respondents toward various factors influencing Quality of work life: Rate various parameters regarding Quality of work life - (From "Highly Satisfied" to "Highly Dissatisfied".)

\begin{tabular}{|c|l|c|c|c|c|c|}
\hline & $\begin{array}{c}\text { Various Parameters regarding Quality } \\
\text { of work life (Please tick any one) }\end{array}$ & $\begin{array}{c}\text { Highly } \\
\text { Satisfied } \\
(5)\end{array}$ & $\begin{array}{c}\text { Satisfied } \\
(4)\end{array}$ & $\begin{array}{c}\text { Neutral } \\
(3)\end{array}$ & $\begin{array}{c}\text { Dissatisfied } \\
(2)\end{array}$ & $\begin{array}{c}\text { Highly } \\
\text { Dissatisfied } \\
(1)\end{array}$ \\
\hline 1. & Health and safety measures & & & & & \\
\hline 2. & Opinion about working hours & & & & & \\
\hline 3. & Opinion about workload & & & & & \\
\hline 4. & Opinion about Respect at workplace & & & & & \\
\hline 5. & Relationship with co-worker & & & & & \\
\hline 6. & $\begin{array}{l}\text { Training programs are given by the } \\
\text { organization }\end{array}$ & & & & & \\
\hline 7. & Grievance handling procedure & & & & & \\
\hline 8. & $\begin{array}{l}\text { Satisfaction about feedback given on } \\
\text { Job Performance }\end{array}$ & & & & & \\
\hline
\end{tabular}

\section{Employee's participation in Decision Making:}

4.1. What is the organizational requirement to take part in decision making process?

a) Job Experiences b) outstanding Performance c) Own Judgement of Management

4.2. Do you get an opportunity to participate in decision making depending on your job experiences?

\begin{tabular}{|l|l|l|}
\hline Job Experiences (Please Tick anyone) & Yes & No \\
\hline Less than 1 year & & \\
\hline 1-3 Years & & \\
\hline 3-4 Years & & \\
\hline 5-6 Years & & \\
\hline 7 Years and above & & \\
\hline
\end{tabular}


5. Women Employee's level of satisfaction regarding various measures to be taken by the organization for improving Quality of Work life:

5.1. Rate Different measures to be taken by the organization for improving Quality of Work Life:

\begin{tabular}{|l|l|c|c|c|c|c|}
\hline No & Factors & $\begin{array}{c}\text { Strongly } \\
\text { Disagree (1) }\end{array}$ & $\begin{array}{c}\text { Disagree } \\
(2)\end{array}$ & $\begin{array}{c}\text { Neutral } \\
(3)\end{array}$ & $\begin{array}{c}\text { Agree } \\
(4)\end{array}$ & $\begin{array}{c}\text { Strongly } \\
\text { Agree (5) }\end{array}$ \\
\hline 1. & Salary & & & & & \\
\hline 2. & Empowerment & & & & & \\
\hline 3. & Health \& Safety & & & & & \\
\hline 4. & Job Security & & & & & \\
\hline 5. & Work environment & & & & & \\
\hline 6. & Leave \& holidays & & & & & \\
\hline 7. & Work time flexibility & & & & & \\
\hline
\end{tabular}

5.2. Work-life Interaction:

\begin{tabular}{|l|l|l|l|l|l|l|}
\hline S.N. & Questions & $\begin{array}{l}\text { Almost } \\
\text { always }\end{array}$ & Often & Sometimes & Rarely & Never \\
\hline 1. & $\begin{array}{l}\text { How often does your work } \\
\text { interfere with your responsibilities } \\
\text { or activities outside of work? }\end{array}$ & & & & & \\
\hline 2. & $\begin{array}{l}\text { How often does your work } \\
\text { interfere with your ability to } \\
\text { develop or maintain connections } \\
\text { and friendships in your } \\
\text { community? }\end{array}$ & & & & & \\
\hline
\end{tabular}

5.3. Job autonomy \&Job security:

You have complete Job security at your organization: Please give your opinion:

\begin{tabular}{|l|l|l|l|l|l|}
\hline Scale of Attitude & Strongly Agree & Agree & Neutral & Disagree & Strongly Disagree \\
\hline Please tick any one & & & & & \\
\hline
\end{tabular}

5.4. Job flexibility:

\begin{tabular}{|c|l|l|l|l|l|l|}
\hline S.N. & Questions & Completely & Often & Sometimes & Rarely & Never \\
\hline 1. & $\begin{array}{l}\text { How much flexibility do } \\
\text { you have in selecting the } \\
\text { location of where you work? }\end{array}$ & & & & & \\
\hline 2. & $\begin{array}{l}\text { How much flexibility do } \\
\text { you have in scheduling } \\
\text { what work you will do? }\end{array}$ & $\begin{array}{l}\text { Strongly } \\
\text { Agree }\end{array}$ & Agree & Neutral & Disagree & $\begin{array}{l}\text { Strongly } \\
\text { Disagree }\end{array}$ \\
\hline 3. & $\begin{array}{l}\text { I have sufficient flexibility in } \\
\text { my job to maintain adequate } \\
\text { work and personal and } \\
\text { family life balance. }\end{array}$ & & & & \\
\hline
\end{tabular}

Thank you for helping me and giving me your precious time.

$$
--0-
$$

